\title{
Vampirism and drakulism: A both cosmetic and curative syncretic approach to avoid future COVID-19 contacts
}

\section{Lorenzo Martini ${ }^{1,2}$}

${ }^{1}$ University of Siena, Department of Pharmaceutical Biotechnologies, Via A. Moro 2, 53100 Siena, Italy, ${ }^{2}$ C.R.I.S.M.A. Inter University Centre for Researched Advanced Medical Systems

Corresponding author: Prof. Lorenzo Martini, E-mail: martini36@unisi.it

Sir,

Clinical vampirism, more commonly known as Renfield's syndrome, is an obsession with drinking blood. The earliest formal presentation of clinical vampirism to appear in the psychiatric literature, with the psychoanalytic interpretation of two cases, was contributed by Richard L. Vanden Bergh and John F. Kelley $[1,2]$. As the authors point out, in 2010, over 50,000 people have become addicted to drinking blood. Many medical publications concerning clinical vampirism can be found in the literature of forensic psychiatry, with the unusual behavior reported as one of many aspects of extraordinary violent crimes [3-5].

Renfield's syndrome typically occurs in three phases. During phase one, called autovampirism or autohemophagia, the sufferer drinks their own blood, often cutting themself in the process. Phase two, called zoophagia, involves eating live animals or drinking animal blood, and can also involve obtaining animal blood for consumption from a butcher or slaughterhouse. During phase three, called true vampirism, the sufferer directs their attention toward other human beings, possibly, stealing blood from hospitals and blood banks or drinking blood directly from a living person. Some suffering from Renfield's syndrome commit violent crimes, including murder, when in true vampirism.

Clinical vampirism was named after the mythical vampire, and is a recognizable, although rare, clinical entity characterized by periodic compulsive blood- drinking, affinity with the dead, and uncertain identity. Hypothetically, it is the expression of an inherited archaic myth, the act of taking blood being a ritual that gives temporary relief. Since ancient times, vampirists have given substance to belief in the existence of supernatural vampires.

The vampire myth has, for millennia, spread widely in one form or another. Tales of the undead with a penchant sucking the life from the living were told even in ancient Egypt, long before Vlad III or Bram Stoker. The specifics of the legend vary in different parts of the world, but the core tale, the one involving blooddrinking revenants, comes up again and again. Modern scholars have looked to the medical literature for an explanation of the universality of the myth, and, in some cases, suggested that what we know as vampirism is, in fact, established on the symptoms of known diseases. However, linking a feared mythical creature with an actual human disease-and the actual people suffering from it-inevitably, leads to consequences.

The most widely known vampire mythology today draws from Slavic folklore and 18th-century stories. These stories tend to involve a recently deceased family member who, upon exhumation, did not seem to have decomposed entirely, and now appears to be full of fresh blood. This was still the popular thinking in early-19th-century New England. Novels such as Carmilla (1871) and Dracula (1897) featured vampires that were mobile, rather underground, and undead. Eventually, light sensitivity and aversion to garlic were introduced to the canon of vampire folklore. In

\footnotetext{
How to cite this article: Martini L. Vampirism and drakulism: A both cosmetic and curative syncretic approach to avoid future COVID-19 contacts. Our Dermatol Online. 2020;11(Supp. 2):26-28.

Submission: 25.05.2020; Acceptance: 01.07.2020

DOI: 10.7241 /ourd.2020S2.10
} 
a 1985 conference talk, Canadian biochemist David H. Dolphin proposed that vampire and werewolf myths drew from a disease known as porphyria, the New York Times reports. The symptoms of congenital erythropoietic porphyria include, in particular, light-sensitive skin, lack of heme-a component of hemoglobin whose lack can produce the drive to bite others and drink their blood - and sensitivity to garlic. It was not the first time, however, that Dolphin had suggested that link, mentioning it in a 1982 speech to the Royal Society and again during a 1984 appearance on NBC.

There are three types of clinical vampirists:

- Vampirists who murder the victim and then suck their blood (sanguinarians),

- Vampirists who suck the victim's blood and then massacre them,

- Vampirists who suck their own blood (autovampirists).

There also exists a subtype who takes pleasure in drinking animal blood; to this category belong cannibales, people organizing black masses and voodoo rituals, as in Louisiana, some regions of Africa, and Mongolia.

All clinical vampires dislike sunshine, hide from all kinds of light-similarly to albinos-and are characterized by porphyria tarda, corresponding to an aberrant overload of iron in the liver due to genetic dysmetabolism. Clinical vampires are also characterized by exceptionally white skin and bloody gums, although not by Count Dracula's prominent canines.

Porphyrias, a group of eight known blood disorders, affect the body's molecular heme-producing mechanisms, with heme being a component of hemoglobin, an oxygen-transporting protein. By binding to iron, heme gives blood its characteristic red color.

The different genetic variations that affect heme production give rise to different clinical manifestations of porphyria, including one variation that may be responsible for the invention of vampire folklore.

Erythropoietic protoporphyria (EPP), the most common variation of porphyria to occur in childhood, sensitizes the skin to light to such an extent that a prolonged exposure to sunshine can spawn painful, disfiguring blisters.
This paper aims to describe the direct and indirect treatment of vampirism and drakulism, without the use of Panhematin or Givlaari and keeping in mind that an excess of iron in the liver must be chelated anyway with EDTA solution and that, because EDTA may chelate calcium, administration of calcium gluconate to compensate for the loss of calcium is necessary. It must be stressed, moreover, that EDTA helps to chelate lead and other heavy metals inhaled because of air pollution or ingested in food.

Moreover, very high dosages of vitamin $\mathrm{C}$, or ascorbates, can afford such iron deprivation in liver mitochondria.

Vitamin C, an excellent reducing agent, aids in increasing absorbable ferrous iron in iron-deficiency anemia. However, even considering that vitamin $\mathrm{C}$ is an efficient antioxidant, it is still uncertain whether vitamin $\mathrm{C}$ provides protection against liver damage caused by excess iron and whether mitochondria are the target effectors of such liver damage [6].

For these reasons, two cases of vampirism are to be treated using the following strategy: administration of $200 \mathrm{ml}$ of EDTA in $0.5 \mathrm{M}$ aqueous solution every 3 hours, $1.5 \mathrm{~g}$ calcium carbonate twice a day, and $15 \%$ palmitoyl ascorbate solution 3 times a day to reach the ultimate dosage of $2.5 \mathrm{~g} /$ day [7] and permission to consume $300 \mathrm{ml}$ of stassanized horse blood a day.

The volunteers were:

a) middle-aged nurse who used to steal blood from the hospital where she worked to drink it at home,

b) young butcher who enjoyed the practice of drinking the blood of hens and pork during slaughter.

After the completion of two full weeks of the treatment, the volunteers showed normal skin and gums and did not feel compelled to consume human blood nor bite other humans or animals.

\section{Consent}

The examination of the patient was conducted according to the Declaration of Helsinki principles.

The authors certify that they have obtained all appropriate patient consent forms. In the form the patient(s) has/have given his/her/ their consent for his/her/their images and other clinical information to be reported in the journal. The patients understand that their names and initials will not be published and due efforts will be made to conceal their identity, but anonymity cannot be guaranteed. 
www.odermatol.com

\section{REFERENCES}

1. Chandan JS, Taylor J, Bradbury-Jones C. COVID-19: a public health approach to manage domestic violence is needed; 2020. The Lancet, May $8^{\text {th }}$.

2. van den Bergh RL, Kelley JF. Vampirism - A review with new observations. Arch Gen Psychiatry. 1964;11:543-7.

3. Hemphill RE, Zabow T. Clinical vampirism. A presentation of 3 cases and a re-evaluation of Haigh, the 'acid-bath murderer'. S Afr Med J. 1983;63:278-81.

4. Clinical presentation and serologic response during a rabies epizootic in captive common vampire bats (Desmodus rotundus). Cárdenas-Canales EM, Gigante CM, Greenberg L, Velasco-Villa A, Ellison JA, Satheshkumar PS, et al. Trop Med Infect Dis. 2020;5:34.

5. Aparisi CA. La aportación de Calmet a la creación de tópicos en la literatura vampírica. Rev Est Frances. 2018;14:15-45.

6. Yves B, Komenan K, N'guessan K, Ubrich A, Ibrahima K, Darius B, et al. Scorbut and purpuric hyperkeratotic skin lesions in the elderly: What relationship? A case report. Our Dermatol Online. 2019;10:372-5.

7. He H, Qiao Y, Zhang Z, Wu Z, Liu D, Liao Z, et al. Dual action of vitamin $C$ in iron supplement therapeutics for iron deficiency anemia: prevention of liver damage induced by iron overload. Food Funct. 2018;9:5390-401.

Copyright by Lorenzo Martini. This is an open access article distributed under the terms of the Creative Commons Attribution License, which permits unrestricted use, distribution, and reproduction in any medium, provided the original author and source are credited.

Source of Support: Nil, Conflict of Interest: None declared. 